University of Nebraska - Lincoln

DigitalCommons@University of Nebraska - Lincoln

\title{
FUM and $B I K$ gene expression contribute to describe fumonisin and bikaverin synthesis in Fusarium verticillioides
}

\author{
I. Lazzaro \\ Università Cattolica del Sacro Cuore \\ M. Busman \\ USDA-ARS \\ P. Battilani \\ Università Cattolica del Sacro Cuore, paola.battilani@unicatt.it \\ R. A. E. Butchko \\ USDA-ARS
}

Follow this and additional works at: https://digitalcommons.unl.edu/usdaarsfacpub

Lazzaro, I.; Busman, M.; Battilani, P.; and Butchko, R. A. E., "FUM and BIK gene expression contribute to describe fumonisin and bikaverin synthesis in Fusarium verticillioides" (2012). Publications from USDAARS / UNL Faculty. 1572.

https://digitalcommons.unl.edu/usdaarsfacpub/1572

This Article is brought to you for free and open access by the U.S. Department of Agriculture: Agricultural Research Service, Lincoln, Nebraska at DigitalCommons@University of Nebraska - Lincoln. It has been accepted for inclusion in Publications from USDA-ARS / UNL Faculty by an authorized administrator of DigitalCommons@University of Nebraska - Lincoln. 


\title{
FUM and BIK gene expression contribute to describe fumonisin and bikaverin synthesis in Fusarium verticillioides
}

\author{
I. Lazzaro ${ }^{\text {a }}$, M. Busman ${ }^{\text {b }}$, P. Battilani ${ }^{\text {a,* }}$, R.A.E. Butchko ${ }^{\text {b }}$ \\ a Institute of Entomology and Plant Pathology, Università Cattolica del Sacro Cuore, Piacenza, Italy \\ b USDA, ARS, National Center for Agricultural Utilization Research, Peoria, IL, USA
}

\section{A R T I C L E I N F O}

\section{Article history:}

Received 18 July 2012

Received in revised form 28 September 2012

Accepted 8 October 2012

Available online 13 October 2012

\section{Keywords:}

Ecology

Water activity

Secondary metabolites

FUM genes

Real-time PCR

\begin{abstract}
A B S T R A C T
Fusarium verticillioides is a maize pathogen that produces toxic secondary metabolites, including fumonisins and bikaverin. The regulation of biosynthetic gene expression and the production of these metabolites are not fully understood and in this study we investigated the influence of water activity (0.955 and 0.990) on the expression of 5 genes (FUM3-FUM8-FUM13-FUM14 and BIK1) in F. verticillioides strains after 14 and 21 days incubation. Fumonisin production and biosynthetic gene expression were greatest at $\mathrm{a}_{\mathrm{w}}=0.990$, and the same trend was observed for bikaverin production, and BIK1 expression. FUM3 and FUM14 were the most highly expressed genes and were positively correlated with the production of $\mathrm{FB}_{1}, \mathrm{FB}_{2}$ and $\mathrm{FB}_{3}$. When FUM14 is more highly expressed than FUM3 the amount of $\mathrm{FB}_{3}$ quantified is higher with respect to $\mathrm{FB}_{1}$; this could be explained by the role of FUM3 in the hydroxylation of $\mathrm{FB}_{3}$ to $\mathrm{FB}_{1}$.
\end{abstract}

(C) 2012 Elsevier B.V. All rights reserved.

\section{Introduction}

Fusarium verticillioides (Sacc.) Nirenberg (teleomorph Gibberella moniliformis Wineland) is a predominant species isolated from maize grown in Italy (Logrieco et al., 2003). It is known to cause pink ear rot and produce toxic secondary metabolites, mainly fumonisins and bikaverin. Fumonisins are mycotoxins harmful to animal and human health (Marasas, 2001); in particular, fumonisin $B_{1}$ $\left(\mathrm{FB}_{1}\right)$ is classified as a potential carcinogen to humans (Group 2B) (IARC, 1993). Bikaverin is a reddish pigment with antibiotic activity against fungi (Son et al., 2008) and antitumor action (Zhan et al., 2007).

During the last decade, the biosynthetic pathway leading to formation of fumonisin has been described and a cluster of biosynthetic genes (FUMs) has been characterized in F. verticillioides. The first step in the pathway is catalyzed by the FUM1-encoded polyketide synthase and results in the formation of a linear polyketide with two methyl groups and a terminal carboxyl group (Proctor et al., 1999). The FUM8-encoded $\alpha$-oxoamine synthase then catalyzes condensation of the polyketide and alanine to form the 20-carbon-long fumonisin backbone (Proctor et al., 2008). The FUM6-encoded cytochrome P450 monooxygenase is postulated to catalyze hydroxylation at carbon atoms 14 (C-14) and C-15 (Seo et al., 2001). The FUM13-encoded dehydrogenase catalyzes the reduction of the C-3

\footnotetext{
* Corresponding author at: Institute of Entomology and Plant Pathology, Università Cattolica del Sacro Cuore, Via Emilia Parmense 84, 29122, Piacenza, Italy. Tel.: + 39 0523599 254; fax: + 390523599256.

E-mail address: paola.battilani@unicatt.it (P. Battilani).
}

carbonyl to a hydroxyl (Butchko et al., 2003b). The FUM2-encoded cytochrome P450 monooxygenase then catalyzes the hydroxylation of C-10 (Proctor et al., 2006). The FUM14-encoded protein then catalyzes the esterification of trycarballylic acids to the C-14 and C-15 hydroxyls (Zaleta-Rivera et al., 2006). Lastly the FUM3-encoded dioxygenase catalyzes the hydroxylation of $\mathrm{C}-5$, leading to fumonisin $\mathrm{FB}_{1}$ and $\mathrm{FB}_{2}$ production (Butchko et al., 2003a).

Fumonisins are produced optimally between 20 and $30{ }^{\circ} \mathrm{C}$ and water activity $\left(\mathrm{a}_{\mathrm{w}}\right)$ between 0.955 and 0.990 and ceases below $10{ }^{\circ} \mathrm{C}$ and at $\mathrm{a}_{\mathrm{w}}$ lower than 0.930 (Marín et al., 1999). FUM1 and FUM19 transcripts were observed from $F$. verticillioides cultures incubated at $20{ }^{\circ} \mathrm{C}$ for 14 days and found to be linearly correlated to fumonisin production (López-Errasquín et al., 2007). These findings have been confirmed by de Oliveira Rocha et al. (2011) in F. verticillioides 7 day-old cultures grown at $25^{\circ} \mathrm{C}$.

FUM1 expression was also used to assay the effects of osmotic and matrix potential in F. verticillioides. FUM1 expression was highest at 12 days during water stress (i.e. $\mathrm{a}_{\mathrm{w}}=0.930$ ) whereas no significant variations were observed under mild water stress $\left(a_{w} 0.950-0.980\right)$ (Jurado et al., 2008). Marín et al. (2010) confirmed that FUM1 transcription was induced under non-ionic water stress at temperatures between 15 and $35{ }^{\circ} \mathrm{C}$ in 10 day-old $F$. verticillioides and Fusarium proliferatum cultures. The effect of $\mathrm{a}_{\mathrm{w}}$ on FUM2 and FUM21 expression in $F$. verticilioides 7,14 , and 21 day-old cultures was investigated, showing that gene expression increases at lower $\mathrm{a}_{\mathrm{w}}$ and that fumonisin production is significantly correlated (Lazzaro et al., 2012).

The $F$. verticillioides bikaverin biosynthetic gene cluster consists of six genes, BIK1 through BIK6 (Brown et al., 2008). BIK1 is the main biosynthetic gene and encodes a polyketide synthase that catalyzes 
the condensation of acetyl- and malynyl-CoA units into the bikaverin precursor (Linnemannstöns et al., 2002; Wiemann et al., 2009). Giordano et al. (1999) demonstrated that high nitrogen concentrations and $\mathrm{pH}>5$ can inhibit bikaverin production while a low nitrogen to carbon ratio and $\mathrm{pH}<5$ induces bikaverin production. In Fusarium fujikuroi, BIK1 expression is repressed at $\mathrm{pH} \geq 5$ and by high nitrogen concentrations, as well as all other BIK genes (Linnemannstöns et al., 2002; Wiemann et al., 2009). In F. verticillioides, the same conditions are conducive for $B I K$ gene cluster expression and bikaverin production as they are for FUM gene cluster expression and fumonisin production (Brown et al., 2008).

The role of environmental conditions on fumonisin and bikaverin production is complex and a better understanding of the mechanisms that regulate gene expression and secondary metabolite production could help clarify the roles of these compounds in nature. Therefore, the aim of this study was to investigate the influence of $a_{w}$ over time on the expression of four FUM genes (FUM3, FUM8, FUM13 and FUM14) as well as one BIK gene (BIK1) in two different $F$. verticillioides strains.

\section{Materials and methods}

\subsection{Fungal isolates, media and inoculum preparation}

Fungal strains used in this study are two fumonisin-producing F. verticillioides, ITEM 10027 (MPVP 294) and ITEM1744, isolated from maize in Tuscany and Sardinia (Italy), respectively. Strains are preserved in $18 \%$ glycerol at $-80{ }^{\circ} \mathrm{C}$ in the fungal collection of ISPA-CNR, Bari (code ITEM) and at the Institute of Entomology and Plant Pathology-UCSC, Piacenza (code MPVP). Isolates were cultured on V8 juice (Campbell Soup Company, Camden, NJ) agar at $25{ }^{\circ} \mathrm{C}$ for 7 days under UVA light ( $12 \mathrm{~h}$ light/12 h dark). Conidia were harvested from plates in $5 \mathrm{ml}$ of sterile water and $1 \mathrm{ml}$ was used to inoculate liquid media to a final concentration of $10^{6}$ conidia/ml. Fumonisin-inducing Malt Extract (ME) and fumonisin-inhibiting Czapek Yeast Autolysate (CYA) were utilized as liquid media $(100 \mathrm{ml})$ for $F$. verticillioides cultures (Frisvad et al., 2007). The $\mathrm{a}_{\mathrm{w}}$ of ME and CYA were adjusted to 0.955 and 0.990 by adding appropriate amounts of glycerol (Giorni et al., 2011). Cultures were incubated in the dark at $25{ }^{\circ} \mathrm{C}$ for 14 and 21 days in static conditions. Three biological replicates were done for each condition (strain, liquid medium, $a_{w}$, incubation time) studied. The mycelium was weighed and used for RNA isolation and gene expression analysis, while the liquid medium from culture filtration was used for metabolite analysis.

\subsection{RNA isolation and gene expression data analysis}

The mycelium was collected by filtration over vacuum on Miracloth (Calbiochem, Germany), frozen in liquid nitrogen, lyophilized overnight and stored at $-80^{\circ} \mathrm{C}$. Total RNA was purified from lyophilized mycelium with the RNeasy Plant Mini Kit (Qiagen, Hilden, Germany) following the manufactures protocol with the addition of the DNase digestion step and stored at $-80{ }^{\circ} \mathrm{C}$. The amount and quality of total RNA was estimated by Nanodrop (Thermo Scientific, Wilmington, DE) and via Bioanalyzer (Agilent, Santa Clara, CA). Total RNA quality control was performed using the RIN (RNA integrity number) (Schroeder et al., 2006).

First strand cDNA was synthesized using $1 \mu \mathrm{g}$ of total RNA, following the iScript cDNA Synthesis kit protocol (Bio-Rad, Hercules, CA) and was stored at $-20{ }^{\circ} \mathrm{C}$. Primer pairs specific to target genes were designed using Primer3 Plus (Untergasser et al., 2007) and DNAMAN 7.0 (Lynnon Corporation, Quebec), on exon-exon junctions in the target mRNA to prevent amplification of genomic DNA template. Primer pairs for FUM3, FUM8, FUM13, FUM14, and BIK1 and for the house-keeping gene $\beta$-tubulin (BT) are listed in Table 1. Primer-gene specificity was tested with $F$. verticillioides cDNA by
PCR using an amplification reaction of $20 \mu \mathrm{l}$ total volume: $10 \mu \mathrm{l} \mathrm{Go}$ Taq Master Mix (Promega, Madison, WI), $1 \mu \mathrm{l}$ cDNA (<250 ng), $2 \mu \mathrm{l}$ each primer $(10 \mu \mathrm{M})$ and $5 \mu \mathrm{l}$ nuclease free water.

Gene expression profiles were determined through quantitative real-time PCR using an MJ Research PTC-200 fitted with a Chromo4 Real-Time PCR detector (Bio-Rad, Hercules, CA). Single strand cDNA (20 ng) was amplified using the following protocol: $95{ }^{\circ} \mathrm{C}$ for $10 \mathrm{~min}$ followed by 40 cycles at $95{ }^{\circ} \mathrm{C}$ for $15 \mathrm{~s}, 55^{\circ} \mathrm{C}$ for $30 \mathrm{~s}$ and $72{ }^{\circ} \mathrm{C}$ for $30 \mathrm{~s}$. Melting curve analysis $\left(60{ }^{\circ} \mathrm{C}\right.$ to $\left.95^{\circ} \mathrm{C}\right)$ confirmed primer pairs specificity. Each sample (biological replicate) was analyzed in triplicate (technical replicate) together with a template-free negative control in each analysis of both target and house-keeping genes. The amplification reaction contained $12.5 \mu \mathrm{l} 2 \mathrm{X}$ iQ STBR Green Supermix (Bio-Rad, Hercules, CA), $3 \mu \mathrm{l}$ of each primer $(10 \mu \mathrm{M})$ and $40 \mathrm{ng}$ of template cDNA and RNase free water to a final volume of $25 \mu$.

Data were analyzed using Opticon Monitor Version 3.1.34 software (Bio-Rad, Hercules, CA). Relative quantification of gene expression was calculated using the $2^{-\Delta \Delta \mathrm{Ct}}$ method (Applied Biosystems User Bulletin \#2 ABI PRISM 7700 Sequence Detection System). The method assumes that when comparing multiple samples using relative quantification, the untreated/control sample is chosen as calibrator (Fusarium cultures on CYA in this study), and the corresponding treated sample is chosen as test (Fusarium cultures on ME in this study). The expression of the target gene correspond to the fold increase (or decrease) of the gene in the test sample compared to the calibrator sample. All data were normalized to $\beta$-tubulin as internal control (Real-Time PCR Application Guide, Bio-Rad, Hercules CA). ANOVA was performed on all gene expression values and fumonisin and bikaverin toxin levels, transforming values by $\mathrm{y}=\ln$ before analysis by PASW statistic 18 (IBM, Armonk, NY).

\subsection{Fumonisin and bikaverin analysis}

Liquid medium from fungal cultures was filtered through $0.2 \mu \mathrm{m}$ acetate filters (Thermo Fisher Scientific, Rochester, NY) and stored at $4{ }^{\circ} \mathrm{C}$. All LC-MS and LC-MS/MS experiments were conducted utilizing a ThermoFinnigan LCQ-DECA (Thermo Scientific, San Jose, CA) ion trap mass spectrometer equipped with an electrospray ionization source, coupled to a ThermoSpectraPhysics high performance liquid chromatography system consisting of an AS4000 autosampler coupled to a P2000 gradient pump. Operation of the chromatography and mass spectrometry instrument and quantitation of the eluting fumonisins and bikaverin were done utilizing ThermoFinnigan Xcalibur software. Elution of analytes was achieved with a gradient

Table 1

ß-tubulin (TUB2), FUM3, FUM8, FUM13, FUM14, BIK1 primers pairs (sequences, size of the product of amplification and sequence of origin from the database at the National Center for Biotechnical Information - NCBI) used for the quantification of gene expression.

\begin{tabular}{|c|c|c|c|c|}
\hline $\begin{array}{l}\text { Primers } \\
\text { pair }\end{array}$ & Gene & Sequence & $\begin{array}{l}\text { Amplicon } \\
\text { size (bp) }\end{array}$ & GenBank ID \\
\hline TUB2 $\mathrm{F}^{1}$ & $\beta$-tubulin & 5'-GGTCAGTGCGGTAACCAAAT-3' & 107 & AF155773.5 \\
\hline TUB2 $\mathrm{R}^{2}$ & & 5'-GAGCTGGAGCTCGGAGGTA-3' & & \\
\hline FUM3 F & FUM3 & 5'-GATAGCCACCTTTTGCAGGA-3' & 137 & AF155773.5 \\
\hline FUM3 R & & 5'-GGCTACACCTCTGGACGAAG-3' & & \\
\hline FUM8 F & FUM8 & 5'-GCCATTATGGTCCTGTCGAG-3' & 115 & AF155773.5 \\
\hline FUM8 R & & 5'-GCCTTTGAGTTGGAGTTTGC-3' & & \\
\hline $\begin{array}{c}\text { FUM13 } \\
\text { F }\end{array}$ & FUM13 & 5'-CGGAGAGATTGTCAGGAGGA-3' & 116 & AF155773.5 \\
\hline $\begin{array}{c}\text { FUM13 } \\
\text { R }\end{array}$ & & 5'-CTGCTGAGCCGACATCATAA-3' & & \\
\hline $\begin{array}{c}\text { FUM14 } \\
\text { F }\end{array}$ & FUM14 & 5'-GTGGCTCTATTGCGACTGGT-3' & 151 & AF155773.5 \\
\hline $\begin{array}{l}\text { FUM14 } \\
\text { R }\end{array}$ & & 5'-GAATTCTTGAATCGAGCTGATGG-3' & & \\
\hline PKS F & BIK1 & 5'-GACCTGGGTGTCGATTCACT-3' & 114 & AF155773.5 \\
\hline PKS R & & 5'-TGAGGTCCTGCACTGTTGAG-3' & & \\
\hline
\end{tabular}

${ }^{1} \mathrm{~F}=$ forward, ${ }^{2} \mathrm{R}=$ reverse. 
flow of methanol and water $(0.3 \%$ acetic acid was added to the mobile phase). The solvent program used a 35-95\% methanol gradient over $25 \mathrm{~min}$. The entire chromatography column flow was directed to the ion source of the mass spectrometer. Operation of the mass spectrometer was in the positive mode. Fumonisin determinations were made in LC-MS mode, monitoring the detection of $\mathrm{m} / \mathrm{z} 722$ $[\mathrm{M}+\mathrm{H}]^{+}$ions for $\mathrm{FB}_{1}$ and $m / z 706[\mathrm{M}+\mathrm{H}]^{+}$ions for $\mathrm{FB}_{2}$ and $\mathrm{FB}_{3}$ (Plattner et al., 1996). Multiple reaction monitoring MS/MS experiments were used for the detection of bikaverin. To achieve effective fragmentation of the bikaverin $[\mathrm{M}+\mathrm{H}]^{+}$ions $(\mathrm{m} / \mathrm{z} 383)$, a normalized collision energy of $50 \%$ was used. The monitoring of the $355 \mathrm{~m} / \mathrm{z}$ fragment ion was used as the basis for quantitation of bikaverin while integrations of LC-MS/MS response were recorded for the $m / z 337,340,355$ and 365 distinctive fragment ions. Quantitations were made by comparison to calibration standards of the fumonisins (Plattner et al., 1996) and bikaverin (Vesonder et al., 1989).

\section{Results}

\subsection{RNA isolation}

All RNA samples had a very good quality, with a RIN ranging from 8 to 10 (RIN values range from $10=$ intact to $1=$ totally degraded).

\subsection{Effect of water activity on metabolite production and gene expression}

Fumonisins were produced by both $F$. verticillioides strains in all conditions in ME media, while it was absent in CYA cultures. ITEM 10027 produced four times as much total fumonisins as ITEM 1744 (43.83 versus $10.17 \mathrm{mg} / \mathrm{kg}$, average total $\mathrm{FBs}$ respectively; Fig. 1). $\mathrm{FB}_{1}$ was the predominant fumonisin in both strains. Fumonisin ratios were $0.09\left(\mathrm{FB}_{2} / \mathrm{FB}_{1}\right)$ and $0.10\left(\mathrm{FB}_{3} / \mathrm{FB}_{1}\right)$ in cultures of ITEM 10027 and $0.13\left(\mathrm{FB}_{2} / \mathrm{FB}_{1}\right)$ and $0.09\left(\mathrm{FB}_{3} / \mathrm{FB}_{1}\right)$ in cultures of ITEM 1744. Water activity of 0.955 reduced significantly fumonisin production (around 50\%) compared to $\mathrm{a}_{\mathrm{w}}=0.990$. Fumonisin production was higher at the later time point when ITEM 10027 was cultured at $\mathrm{a}_{\mathrm{w}}=$ 0.955. In contrast, fumonisin accumulation was higher at the early time point when ITEM 10027 was cultured at $\mathrm{a}_{\mathrm{w}}=0.990$. Interestingly, ITEM 1744 was affected differently with regard to fumonisin production at different water activities: it accumulated more fumonisins at 14 days versus 21 days when cultured at $\mathrm{a}_{\mathrm{w}}=0.955$, but accumulated more fumonisins at 21 days versus 14 days when cultured at $\mathrm{a}_{\mathrm{w}}=0.990$ (Fig. 1), as pointed out by the significant interaction strain $* \mathrm{a}_{\mathrm{w}} *$ time. Bikaverin production was significantly $(\mathrm{P}<0.01)$ higher in ITEM 10027 than in ITEM 1744 (5.11 versus $1.75 \mathrm{mg} / \mathrm{kg}$, average bikaverin respectively). Bikaverin was significantly $(\mathrm{P}<0.01)$ reduced (around 66\%) at lower $a_{w}$ respect to $a_{w}=0.990$ (Table 2 ). Bikaverin production by ITEM 10027 and ITEM 1744 reflected the trend of fumonisin production.

The production of fumonisin appeared to be correlated with the mycelial growth, and tended to increase with mycelial production, especially with $\mathrm{a}_{\mathrm{w}}=0.990$. Also bikaverin production was positively correlated with mycelial growth, and showed in both strains an exponential increase with the increment of fungal biomass $\left(\mathrm{R}^{2}=\right.$ 0.854).

FUM genes and BIK1 were significantly $(\mathrm{P}<0.01$ and $\mathrm{P}<0.05$ respectively) more highly expressed in ITEM 1744 (Table 2). Fumonisin and bikaverin production were significantly $(\mathrm{P}<0.01)$ higher, however, in ITEM 10027. FUM3 and FUM14 were the most highly expressed genes at all conditions considered and the ones most affected by $a_{w}$ variations. Their expression was lower at $\mathrm{a}_{\mathrm{w}}=0.955$ than at $\mathrm{a}_{\mathrm{w}}=$ 0.990 (Fig. 2). BIK1 expression was significantly reduced with low $\mathrm{a}_{\mathrm{w}}$ values compared to $\mathrm{a}_{\mathrm{w}}=0.990$, as FUM3 and FUM14 (Table 2). The combined effect of $\operatorname{strain} * \mathrm{a}_{\mathrm{w}} *$ incubation time was significant for all FUM gene expression and FBs production (Table 2).

\section{Discussion}

Environmental conditions could affect secondary metabolite gene expression and production. In order to observe the role of $a_{w}$ on fumonisin metabolism in a time-course during which $F$. verticillioides could produce fumonisin on maize ears, we studied the effects of high $\left(\mathrm{a}_{\mathrm{w}}=0.990\right)$ and low $\left(\mathrm{a}_{\mathrm{w}}=0.955\right.$, commonly measured in ripe maize (Battilani et al., 2011)) water activity on the expression of BIK and FUM genes and on production of bikaverin and fumonisins, in 14 and 21 day-old cultures.

F. verticillioides strains used in this study were recovered from maize and were confirmed to be fumonisin-producers (Etcheverry et al., 2009; Moretti et al., 1995). They showed different patterns of fumonisin production: ITEM 1744 had a classical pattern of FBs produced $\left(\mathrm{FB}_{1}>\mathrm{FB}_{2}>\mathrm{FB}_{3}\right.$; de Oliveira Rocha et al., 2011; LópezErrasquín et al., 2007) while ITEM 10027 presented one of the minor chemotypes: $\mathrm{FB}_{1}>\mathrm{FB}_{3}>\mathrm{FB}_{2}$ (Szecsi et al., 2010), in accord with our previous data (ITEM1744: $2800 \mathrm{FB}_{1}>521 \mathrm{FB}_{2}>480 \mathrm{FB}_{3} \mu \mathrm{g} / \mathrm{kg}$; ITEM 10027: $7720 \mathrm{FB}_{1}>2180 \mathrm{FB}_{3}>2070 \mathrm{FB}_{2} \mu \mathrm{g} / \mathrm{kg}$ ) (Lazzaro et al., 2012). Water activity significantly affected fumonisin production with $\mathrm{a}_{\mathrm{w}}=0.990$ supporting more production than $\mathrm{a}_{\mathrm{w}}=0.955$. This is in accord with Mogensen et al. (2009) who reported decreasing total fumonisin production at $\mathrm{a}_{\mathrm{w}}$ between 0.990 and 0.955 , and with Marín

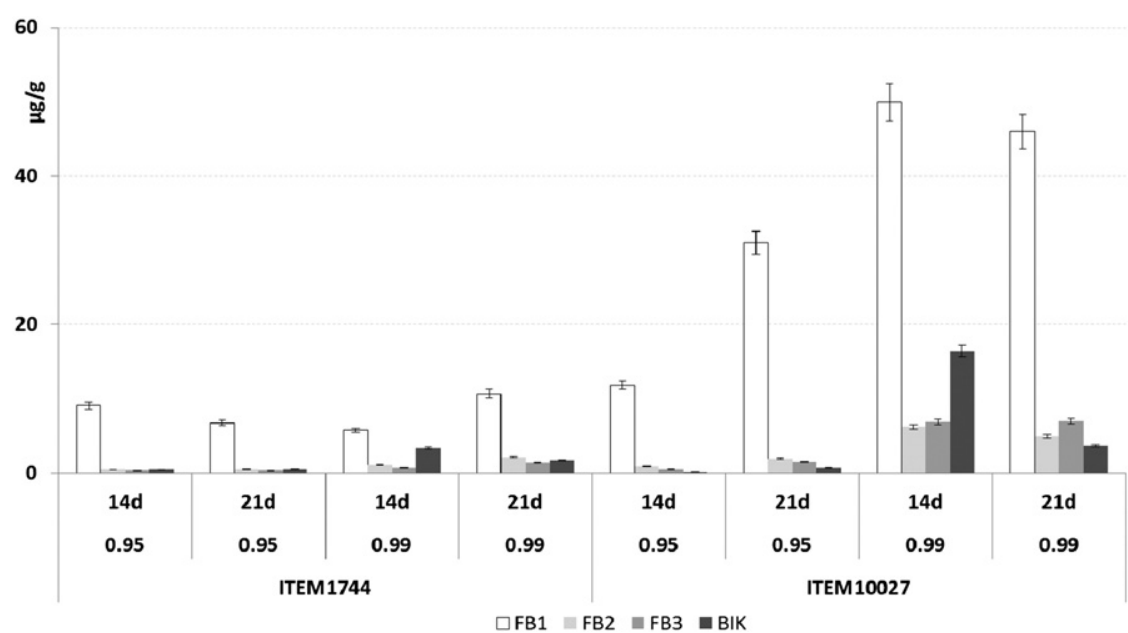

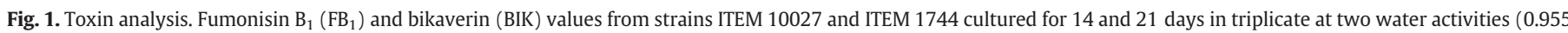
and 0.990). 
Table 2

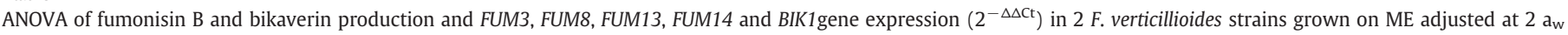
(0.955-0.990) and incubated for 14-21 days.

\begin{tabular}{|c|c|c|c|c|c|c|c|c|c|c|}
\hline Factors & $\mathrm{FB}_{1}^{\mathrm{a}}$ & $\mathrm{FB}_{\text {tot }}{ }^{\mathrm{b}}$ & BIK & FUM3 & FUM8 & FUM13 & FUM14 & BIK1 & $\mathrm{FB}_{2} / \mathrm{FB}_{1}$ & $\mathrm{FB}_{3} / \mathrm{FB}_{1}$ \\
\hline Strain & $* * \mathrm{c}$ & $* *$ & $* *$ & $* *$ & $* *$ & $* *$ & $* *$ & * & $* *$ & * \\
\hline 10027 & 36.02 & 43.83 & 5.11 & 0.54 & 0.52 & 0.26 & 0.79 & 0.15 & 0.09 & 0.10 \\
\hline 1744 & 8.3 & 10.17 & 1.75 & 1.52 & 1.02 & 1.17 & 2.15 & 0.55 & 0.13 & 0.09 \\
\hline$a_{w}$ & $* *$ & $* *$ & $* *$ & $* *$ & - & - & $* *$ & $* *$ & $* *$ & ** \\
\hline 0.955 & 16.17 & 18.07 & 0.47 & 0.34 & 0.69 & 0.54 & 0.49 & 0.11 & 0.07 & 0.05 \\
\hline 0.990 & 28.16 & 35.93 & 5.42 & 1.58 & 0.85 & 0.89 & 2.25 & 0.54 & 0.16 & 0.14 \\
\hline Time & - & - & - & $* *$ & - & - & $* *$ & * & - & $*$ \\
\hline 14 & 19.39 & 23.82 & 4.96 & 0.46 & 0.68 & 0.49 & 0.71 & 0.12 & 0.13 & 0.09 \\
\hline 21 & 24.95 & 30.18 & 1.88 & 1.59 & 0.88 & 0.95 & 2.22 & 0.58 & 0.11 & 0.10 \\
\hline Strain $* a_{w}$ & $*$ & $*$ & - & - & $* *$ & - & - & - & $* *$ & $*$ \\
\hline Strain $*$ time & - & - & - & $* *$ & $* *$ & - & $* *$ & - & - & - \\
\hline$a_{w} *$ time & - & - & - & $* *$ & $* *$ & $* *$ & $* *$ & $* *$ & - & - \\
\hline Strain $* a_{w} *$ time & $* *$ & $* *$ & - & $* *$ & $* *$ & $* *$ & $* *$ & - & - & - \\
\hline
\end{tabular}

a Levels of fumonisin and bikaverin are expressed as ppm.

b FBtot indicates the combined concentration of $\mathrm{FB}_{1}, \mathrm{FB}_{2}$ and $\mathrm{FB}_{3}$.

c ${ }^{* *}$ indicates significant at $\mathrm{p} \leq 0.01$; * indicates significant at $\mathrm{P} \leq 0.05$; and - indicates not significant.

et al. (1995) that indicated an $\mathrm{a}_{\mathrm{w}}$ between 0.956 and 0.968 as supporting the production at both 25 and $30{ }^{\circ} \mathrm{C}$.

Previous studies on FUM gene expression were limited to FUM1. Jurado et al. (2008) found that FUM1 transcription was higher at $\mathrm{a}_{\mathrm{w}}=0.98$ compared to 0.93 at $25^{\circ} \mathrm{C}$ when $\mathrm{a}_{\mathrm{w}}$ was modified with glycerol, while with an ionic stress, FUM1 expression was highest at $\mathrm{a}_{\mathrm{w}}$ between 0.93 and 0.95 . More recently, it has been reported that FUM1 expression is greater at $\mathrm{a}_{\mathrm{w}}=0.955$ compared to 0.982 , with differences observed at different temperatures (Marín et al., 2010). In this study we found that the expression of all FUM genes analyzed was higher at $\mathrm{a}_{\mathrm{w}}=0.990$ compared to 0.955 . Likewise, fumonisin production was higher at $\mathrm{a}_{\mathrm{w}}=0.990$ than at 0.955 , underlining that gene expression and secondary metabolite production followed the same trend (Proctor et al., 2003).

FUM14 is required for $\mathrm{FB}_{3}$ and $\mathrm{FB}_{4}$ formation, while FUM3 catalyzes the hydroxylation of $\mathrm{FB}_{3}$ and $\mathrm{FB}_{4}$ to $\mathrm{FB}_{1}$ and $\mathrm{FB}_{2}$ respectively (Butchko et al., 2003a). Interestingly, the $\mathrm{FB}_{3} / \mathrm{FB}_{1}$ ratio was higher in cultures grown with $\mathrm{a}_{\mathrm{w}}=0.990$ compared to cultures from $\mathrm{a}_{\mathrm{w}}=$ 0.955; at $\mathrm{a}_{\mathrm{w}}=0.990$, FUM14 is more highly expressed than FUM3 and we hypothesize that the higher amount of $\mathrm{FB}_{3}$ quantified with respect to $\mathrm{FB}_{1}$ is a consequence of this difference. The last step of fumonisin biosynthesis, FUM3 mediated hydroxylation of $\mathrm{FB}_{3}$ to $\mathrm{FB}_{1}$ is less enhanced due to the lower FUM3 expression, which results in potentially less FUM3 enzyme to catalyze C-5 hydroxylation.

The addition of glycerol into the growth medium modify $\mathrm{a}_{\mathrm{w}}$ by causing an increase in osmotic pressure; therefore, the High Osmolarity
Glycerol (HOG) pathway should be taken into consideration. Kohut et al. (2009) found that the HOG-type MAP kinase (MAPK) influenced both the expression of FUM1 and FUM8 and $\mathrm{FB}_{1}$ production during N-starvation; moreover Ádám et al. (2008) observed that Fphog1, a HOG-type MAPK gene cloned from F. proliferatum, was not involved in transcriptional regulation under salt and hyperosmolar stress conditions. A similar role of HOG-type MAPK in F. verticillioides could be hypothesized and it would be interesting to study the HOG response in F. verticillioides cultures.

We investigated the expression of BIK1 observing that it was enhanced by the same conditions useful for the FUM genes, with the expression higher at $\mathrm{a}_{\mathrm{w}}=0.990$ compared to 0.955 , in agreement with Brown et al. (2008). Furthermore, bikaverin production was higher at $\mathrm{a}_{\mathrm{w}}=0.990$ compared to 0.955 .

To our knowledge, this is the first report of the effects of $\mathrm{a}_{\mathrm{w}}$ on FUM3, FUM8, FUM13 and FUM14 expression in F. verticillioides. We have also demonstrated the effects of $\mathrm{a}_{\mathrm{w}}$ on bikaverin production and the expression of BIK1 and also confirmed the production of bikaverin under fumonisin inducing conditions. Furthermore, we identified a correlation between FUM gene and BIK gene expression.

The similar effects of $\mathrm{a}_{\mathrm{w}}$ on FUM and BIK gene expression and production of the corresponding metabolites suggest that fumonisin and bikaverin synthesis could be connected by a genetic regulatory systems that relays environmental signals, in this case $\mathrm{a}_{\mathrm{w}}$, to the nucleus in order to suppress or activate FUM and BIK gene expression. It was reported that nitrogen starvation resulted in induced FUM1 and FUM8 expression

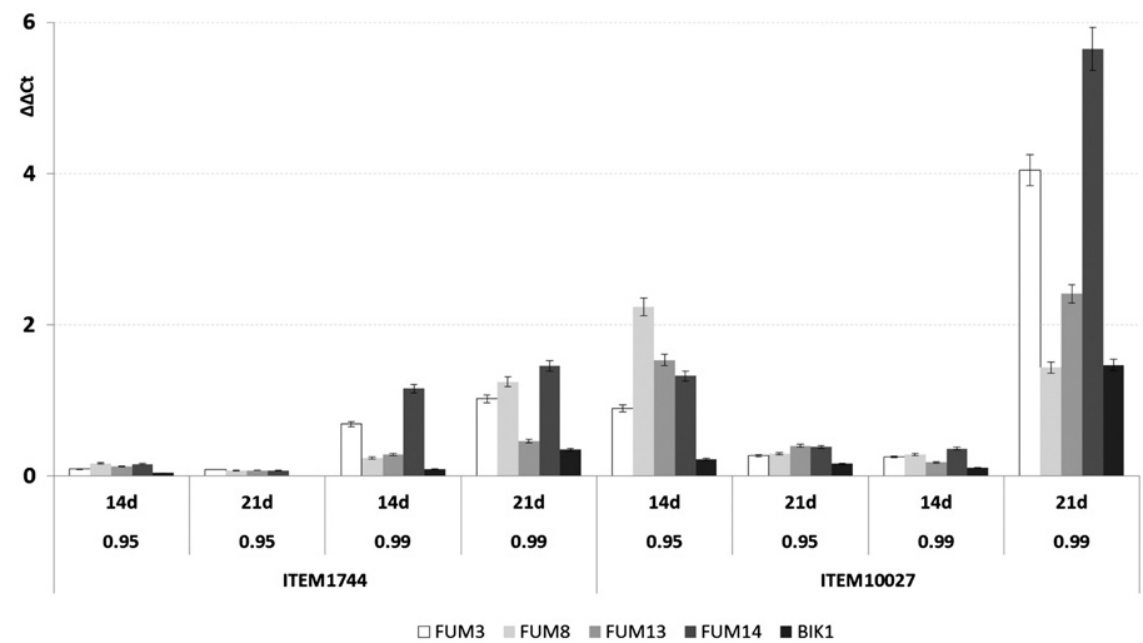

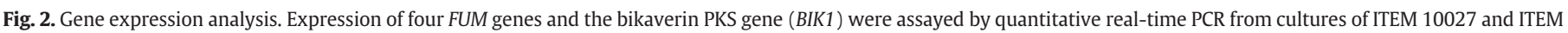
1744 grown for 14 and 21 days at two water activities (0.955 and 0.990). 
and increased fumonisin production in both F. proliferatum (Kohut et al., 2009) and $F$. verticillioides, suggesting that fumonisin biosynthesis is regulated by the global nitrogen regulatory gene AREA (Kim and Woloshuk, 2008). AREA is postulated to regulate BIK gene expression in F. fujikuroi as well (reviewed in Limón et al., 2010). Even though there are correlations between the expression of the FUM and BIK gene clusters and production of the corresponding secondary metabolites, strain specific differences are apparent, probably due to different genetic backgrounds.

The regulation of secondary metabolite gene clusters and the production of metabolites are of interest both with regard to mechanisms of transcriptional regulation as well as for food safety. As bikaverin is known to have an antitumor activity against mammalian cell lines (Zhan et al., 2007), the toxicity of fumonisin could be hypothesized to be reduced when the compounds co-occur in contaminated products. Studying relationships between environmental factors and secondary metabolite production could also provide insights into the role of secondary metabolites in the ecology of the organisms that produce them and into the possible co-occurrence of different metabolites and their interaction in causing toxic effects in animals and humans.

\section{Acknowledgments}

This work was supported by EC KBBE-2007-222690-2 MYCORED. The first author carried out this work within the PhD School Agrisystem of the UCSC, Italy. We thank Crystal E. Probyn for technical assistance. Mention of trade names or commercial products in this article is solely for the purpose of providing specific information and does not imply recommendation or endorsement by the US Department of Agriculture. USDA is an equal opportunity provider and employer.

\section{References}

Ádám, A.L., Kohut, G., Hornok, L., 2008. Fphog1, a HOG-type MAP kinase gene, is involved in multistress response in Fusarium proliferatum. Journal of Basic Microbiology 48, 151-159.

Battilani, P., Formenti, S., Ramponi, C., Rossi, V., 2011. Dynamic of water activity in maize hybrids is crucial for fumonisin contamination in kernels. Journal of Cereal Science 54, 467-472.

Brown, D.W., Butchko, R.A.E., Proctor, R.H., 2008. Genomic analysis of Fusarium verticillioides. Food Additives and Contaminants 25, 1158-1165.

Butchko, R.A.E., Plattner, R.D., Proctor, R.H., 2003a. FUM9 is required for C-5 hdroxylation of fumonisins and complements themeitotically defined Fum3 locus in Gibberella moniliformis. Applied and Environmental Microbiology 69, 6935-6937.

Butchko, R.A.E., Plattner, R.D., Proctor, R.H., 2003b. FUM13 encodes a short chain denydrogenase/reductase required for C-3 carbonyl reduction during fumonisin biosynthesis in Gibberella moniliformis. Journal of Agricultural and Food Chemistry 51, 3000-3006.

de Oliveira Rocha, L., Martins, Reis G., Nascimento da Silva, V., Braghini, R., Geraldes Teixeira, M.M., Corrêa, B., 2011. Molecular characterization and fumonisin production by Fusarium verticillioides isolated from corn grains of different geographic origins in Brazil. International Journal of Food Microbiology 45, 9-21.

Etcheverry, M.G., Scandolara, A., Nesci, A., Vilas Boas Ribeiro, M.S., Pereira, P., Battilani, P., 2009. Biological interactions to select biocontrol agents against toxigenic strains of Aspergillus flavus and Fusarium verticillioides from maize. Mycopathologia 167, 287-295.

Frisvad, J.C., Smedsgaard, J., Samson, R.A., Larsen, T.O., Thrane, U., 2007. Fumonisin B production by Aspergillus niger. Journal of Agricultural and Food Chemistry 55, 9727-9732.

Giordano, W., Avalos, J., Cerdá-Olmedo, E., Domenech, C.E., 1999. Nitrogen availability and production of bikaverin and gibberellins in Gibberella fujikuroi. FEMS Microbiology Letters 173, 389-393.

Giorni, P., Magan, N., Pietri, A., Battilani, P., 2011. Growth and aflatoxin production of an Italian strain of Aspergillus flavus: influence of ecological factors and nutritional substrates. World Mycotoxin Journal 4, 425-432.

International Agency for Research on Cancer (IARC), 1993. IARC monographs on the evaluation of carcinogenic risks to humans. Some Naturally Occurring Substances: Food Items and Constituents, Heterocyclic Aromatic Amines and Mycotoxins. IARC Press, Lyon, pp. 445-466.

Jurado, M., Marìn, P., Magan, N., Gonzalez-Jaen, M.T., 2008. Relationship between solute and matric potential stress, temperature, growth and FUM1 gene expression in two Fusarium verticillioides strains from Spain. Applied and Environmental Microbiology 74, 2032-2036.

Kim, H., Woloshuk, C.P., 2008. Role of AREA a regulator of nitrogen metabolism, during colonization of maize kernels and fumonisin biosynthesis in Fusarium verticillioides. Fungal Genetics and Biology 45, 947-953.
Kohut, G., Ádám, A.L., Fazekas, B., Hornok, L., 2009. N-starvation stress induced FUM gene expression and fumonisin production is mediated via the HOG-type MAPK pathway in Fusarium proliferatum. International Journal of Food Microbiology 130, 65-69.

Lazzaro, I., Susca, A., Mulè, G., Ritieni, A., Ferracane, R., Marocco, A., Battilani, P., 2012 Effects of temperature and water activity on FUM2 and FUM21 gene expression and fumonisin B production in Fusarium verticillioides. European Journal of Plant Pathology http://dx.doi.org/10.1007/s10658-012-0045-y.

Limón, C., Rodríguez-Ortiz, R., Avalos, J., 2010. Bikaverin production and applications. Applied Microbiology and Biotechnology 87, 21-29.

Linnemannstöns, P., Schulte, J., Prado, M.M., Proctor, R.H., Avalos, J., Tudzynski, B., 2002 The polyketide synthase gene pks4 from Gibberella fujikuroi encodes a key enzyme in the biosynthesis of the red pigment bikaverin. Fungal Genetics and Biology 37, 134-148.

Logrieco, A., Bottalico, A., Mule, G., Moretti, A., Perrone, G., 2003. Epidemiology of toxigenic fungi and their associated mycotoxins for some Mediterranean crops. European Journal of Plant Pathology 109, 645-667.

López-Errasquín, E., Vázquez, C., Jiménez, M., González-Jaén, M.T., 2007. Real-time RTPCR assay to quantify the expression of fum 1 and fum 19 genes from the fumonisinproducing Fusarium verticillioides. Journal of Microbiological Methods 68, 312-317.

Marasas, W.F.O., 2001. Discovery and occurrence of the fumonisins: a historical perspective. Environmental Health Perspectives 109, 239-243.

Marín, S., Sanchis, V., Vinas, I., Canela, R., Magan, N., 1995. Effect of water activity and temperature on growth and fumonisin $B_{1}$ and $B_{2}$ production by Fusarium proliferatum and F. moniliforme on maize grain. Letters in Applied Microbiology 21, 298-301.

Marín, S., Magan, N., Serra, J., Ramos, A.J., Canela, R., Sanchis, V., 1999. Fumonisin B production and growth of Fusarium moniliforme and Fusarium proliferatum on maize, wheat and barley grain. Journal of Food Science 64, 921-924.

Marín, P., Magan, N., Vazquez, C., González-Jaén, M.T., 2010. Differential effect of environmental conditions on the growth and regulation of the fumonisin biosynthetic gene FUM1 in the maize pathogens and fumonisin producers Fusarium verticillioides and Fusarium proliferatum. FEMS Microbiology Ecology 73, 303-311.

Mogensen, J.M., Nielsen, K.F., Samson, R.A., Frisvad, J.C., Thrane, U., 2009. Effect of temperature and water activity on the production of fumonisins by Aspergillus niger and different Fusarium species. BMC Microbiology 9, 281.

Moretti, A., Bennet, G.A., Logrieco, A., Bottalico, A., Beremand, M.N., 1995. Fertility of Fusarium moniliforme from maize and sorghum related to fumonisin production in Italy. Mycopathologia 131, 25-29.

Plattner, R.D., Weisleder, D., Poling, S.M., 1996. Analytical determination of fumonisins and other metabolites produced by Fusarium moniliforme and related species on corn. In: Jackson, L.S., De Vries, J.W., Bullerman, L.B. (Eds.), Fumonisins in Food. Plenum Press, New York, pp. 57-64.

Proctor, R.H., Desjardins, A.E., Plattner, R.D., Hohn, T.M., 1999. A polyketide synthase gene required for biosynthesis of fumonisin mycotoxins in Gibberella fujikuroi mating population A. Fungal Genetics and Biology 27, 100-112.

Proctor, R.H., Brown, D.W., Plattner, R.D., Desjardins, A.E., 2003. Co-expression of fifteen contiguous genes delineates a fumonisin biosynthetic gene cluster in Gibberella moniliformis. Fungal Genetics and Biology 38, 237-249.

Proctor, R.H., Plattner, R.D., Desjardins, A.E., Busman, M., Butchko, R.A.E., 2006 Fumonisin production in the maize pathogen Fusarium verticillioides: genetic basis of naturally occurring chemical variation. Journal of Agricultural and Food Chemistry 54, 2424-2430.

Proctor, R.H., Busman, M., Seo, J.A., Lee, Y.W., Plattner, R.D., 2008. A fumonisin biosynthetic gene cluster in Fusarium oxysporum strain 0-1890 and the genetic basis for B versus $C$ fumonisin production. Fungal Genetics and Biology 45, 1016-1026.

Schroeder, A., Mueller, O., Stocker, S., Salowsky, R., Leiber, M., Gassmann, M., Lightfoot S., Menzel, W., Granzow, M., Ragg, T., 2006. The RIN: an RNA integrity number for assigning integrity values to RNA measurements. BMC Molecular Biology 7, 3.

Seo, J.A., Proctor, R.H., Plattner, R.D., 2001. Characterization of four clustered and coregulated genes associated with fumonisin biosynthesis in Fusarium verticillioides. Fungal Genetics and Biology 34, 155-165.

Son, S.W., Kim, H.Y., Choi, G.J., Lim, H.K., Jang, K.S., Lee, S.O., Lee, S., Sung, N.D., Kim, J.C., 2008. Bikaverin and fusaric acid from Fusarium oxysporum show antioomycete activity against Phytophthora infestans. Journal of Applied Microbiology 104, 692-698.

Szecsi, A., Szekeres, A., Bartok, T., Oros, G., Bartok, M., Mesterhazy, A., 2010. Fumonisin $\mathrm{B}_{1}-4$-producing capacity of Hungarian Fusarium verticillioides isolates. World Mycotoxin Journal 3, 67-76.

Untergasser, A., Nijveen, H., Rao, X., Bisseling, T., Geurts, R., Leunissen, J.A.M., 2007 Primer3Plus, an enhanced web interface to Primer3. Nucleic Acids Research 35 W71-W74.

Vesonder, R., Haliburton, J., Golinski, P., 1989. Toxicity of field samples and Fusarium moniforme from feed associated with equine-leucoencephalomalacia. Archives of Environmental Contamination and Toxicology 18, 439-442.

Wiemann, P., Willmann, A., Straeten, M., Kleigrewe, K., Beyer, M., Humpf, H.U., Tudzynski, B., 2009. Biosynthesis of the red pigment bikaverin in Fusarium fujikuroi: genes, their function and regulation. Molecular Microbiology 72, 931-946.

Zaleta-Rivera, K., Xu, C., Yu, F., Butchko, R.A.E., Proctor, R.H., Hidalgo-Lara, M.E., Raza, A., Dussault, P.H., Du, L., 2006. Bidomain nonribosomal peptide synthetase encoded by FUM14 catalyzes the formation of tricarballylic esters in the biosynthesis of fumonisins. Biochemistry 45, 2561-2569.

Zhan, J., Burns, A.M., Liu, M.X., Faeth, S.H., Gunatilaka, A.A., 2007. Search for cell motility and angiogenesis inhibitors with potential anticancer activity: beauvericin and other constituents of two endophytic strains of Fusarium oxysporum. Journal of Natural Products 70, 227-232. 